Personalidade Acadêmica Homenageada:

Raymundo Juliano Feitosa (Universidade Federal do Rio Grande do Norte - UFRN)

\title{
“NEGA DE NINGUÉM”: A CONDIÇÃO DA MULHER NEGRA NO MERCADO DE TRABALHO CONTEMPORÂNEO
}

\section{“DENY NOBODY”: THE CONDITION OF BLACK WOMAN IN THE CONTEMPORARY LABOR MARKET}

LARYSSA FARIA

Graduanda em Direito, modalidade integral, pela Escola Superior Dom Helder Câmara. Belo Horizonte - MG. E-mail: laryssafaria777@gmail.

CAIO AUGUSTO SOUZA LARA

Mestre e Doutor em Direito pela Faculdade de Direito da Universidade Federal de Minas Gerais - UFMG. Professor da Escola Superior Dom Helder Câmara. Pesquisador Associado ao Programa RECAJ-UFMG - Acesso à Justiça e Solução de Conflitos. Secretário de Comunicação do Conselho Nacional de Pesquisa e Pósgraduação em Direito - CONPEDI. Belo Horizonte - MG. E-mail: caiolarabh@yahoo.com.br.

\section{RESUMO}

O tema-problema da pesquisa que se pretende desenvolver é a situação da mulher negra no ramo laboral, desde o período escravocrata até à sociedade hodierna brasileira. A Constituição Federal de 1988 - norma de maior hierarquia no sistema jurídico brasileiro - assegura a todos os indivíduos à dignidade. Entretanto, a condição da mulher negra no mercado de trabalho contemporâneo reflete que esse direito não é resguardado a todos na prática. Logo, faz-se necessário analisar os fatores e efeitos dessa problemática complexa, mas não recente. Apesar de a Abolição da escravidão 


\section{Personalidade Acadêmica Homenageada:}

Raymundo Juliano Feitosa (Universidade Federal do Rio Grande do Norte - UFRN)

ter sido efetivada no papel, seus resquícios ainda refletem na sociedade contemporânea, visto que a condição degradante da mulher negra no mercado de trabalho hodierno enfrenta diversos desafios, como o machismo, o racismo e a falta de oportunidades nos ramos educacionais e trabalhistas. Destarte, o pouco ou nenhum acesso de muitas jovens negras a um ensino médio e superior de qualidade acabam comprometendo a carreira profissional das mesmas, pois muitas acabam sendo exploradas na área trabalhista, ou abrem mão dos estudos para se dedicarem às tarefas domésticas - que muitas vezes propiciam, de forma velada, a ocorrência de violência sexual, física e/ou psicológica. Nesse sentido, a discriminação para com as mulheres, especialmente as negras e de descendência afro-brasileira, ocorre pela diferença salarial, dificuldade de acesso a cargos de liderança dentro de empresas e cargos públicos, assédio e comentários que podem se constituir violência psicológica sofrida por essas cidadãs no meio trabalhista. Sendo assim, a crença de que mulheres negras existem para servir e serem subjugadas está tão introjetada na sociedade, que muitas delas passam a aceitar, de fato, o assédio sexual, as diferenças salariais e 0 racismo praticados em seus locais de trabalho, pois acreditam que nada pode mudar isso. Dessa forma, a perpetuação de mitos dessa natureza faz com que a mulher negra seja ainda vista em condição análoga a de escrava, e não como ser humano livre, digno de ser respeitado. O problema objeto da investigação científica proposta é: como garantir o acesso eficaz da mulher negra ao mercado de trabalho, sem discriminação racial e de gênero, posto que, no Brasil, não há igualdade de oportunidades? A partir das reflexões preliminares sobre o tema, é possível afirmar inicialmente que uma educação voltada para a desconstrução de ideologias machistas e racistas desde o núcleo familiar, perpassando pelas instituições escolares e pelos diversos ramos laborais, bem como políticas públicas que permitam a inclusão efetiva sem discriminação da mulher negra no mercado de trabalho, são medidas que podem assegurar uma condição digna à essas cidadãs mediante à situação degradante que as mulheres negras eram - e ainda são - submetidas. O objetivo geral do trabalho é analisar a circunstância contemporânea da mulher negra no mercado de trabalho atual, de modo a constatar suas causas e efeitos na vida desses indivíduos, uma vez que essa problemática atravessa gerações. A pesquisa que se propõe pertence à 
Personalidade Acadêmica Homenageada:

Raymundo Juliano Feitosa (Universidade Federal do Rio Grande do Norte - UFRN)

vertente metodológica jurídico-sociológica. No tocante ao tipo de investigação, foi escolhido, na classificação de Witker (1985) e Gustin (2010), o tipo jurídico-projetivo. O raciocínio desenvolvido na pesquisa será predominantemente dialético. De acordo com a técnica de análise de conteúdo, afirma-se que se trata de uma pesquisa teórica, o que será possível a partir da análise de conteúdo dos textos doutrinários, normas e demais dados colhidos na pesquisa. Como conclusão parcial da investigação científica, tem-se que o não reconhecimento da dignidade da mulher negra no mercado laboral contemporâneo contribui para as diversas formas de exploração sofridas por esse grupo social oprimido em meio ao sistema capitalista, bem como a perpetuação da negação de seus direitos.

PALAVRAS-CHAVE: Direito do Trabalho; Feminismo Negro; Gênero.

\section{REFERÊNCIAS}

ALMEIDA, Carlos Alberto Lima de. O curso de Direito e a questão racial. Revista Jurídica - UNICURITIBA, Curitiba, v. 1, n. 42, p. 179 - 213, 2016. Disponível em: http://revista.unicuritiba.edu.br/index.php/RevJur/article/view/1490/1019. Acesso em: 21 maio 2019.

ALVES, Alé. Ângela Davis: "Quando a mulher negra se movimenta, toda a estrutura da sociedade se movimenta com ela". El País, Salvador, 28 jul. 2017. Seção Feminismo. Disponível em: https://brasil.elpais.com/brasil/2017/07/27/politica/1501114503_610956.html. Acesso em: 6 maio 2019.

BRASIL. Constituição da República Federativa do Brasil de 1988. Disponível em: http://www.planalto.gov.br/ccivil_03/Constituicao/Constituiçao.htm. Acesso em: 2 maio 2019.

Feminist.

UNIVERSIDADE FEDERAL DO RECÔNCAVO DA BAHIA. Curso Black https://ufrb.edu.br/portal/component/chronoforms5/?chronoform=ver-evento\&id=240. Acesso em: 6 maio 2019.

FREIRE Paulo. Pedagogia da autonomia: saberes necessários à pratica educativa. São Paulo: Paz e Terra, 1996. 
Personalidade Acadêmica Homenageada:

Raymundo Juliano Feitosa (Universidade Federal do Rio Grande do Norte - UFRN)

GUSTIN, Miracy Barbosa de Sousa; DIAS, Maria Tereza Fonseca. (Re)pensando a pesquisa jurídica: teoria e prática. 3a․ ed. Belo Horizonte: Del Rey, 2010.

HAZAN, Ellen Mara Ferraz. Mulheres na efetivação dos direitos humanos e sociais. Belo Horizonte: RTM, 2017.

IHERING, Rudolf Von. A luta pelo direito. São Paulo: Revista dos Tribunais, 1987.

WITKER, Jorge. Como elaborar uma tesis en derecho: pautas metodológicas y técnicas para el estudiante o investigador del derecho. Madrid: Civitas, 1985. 